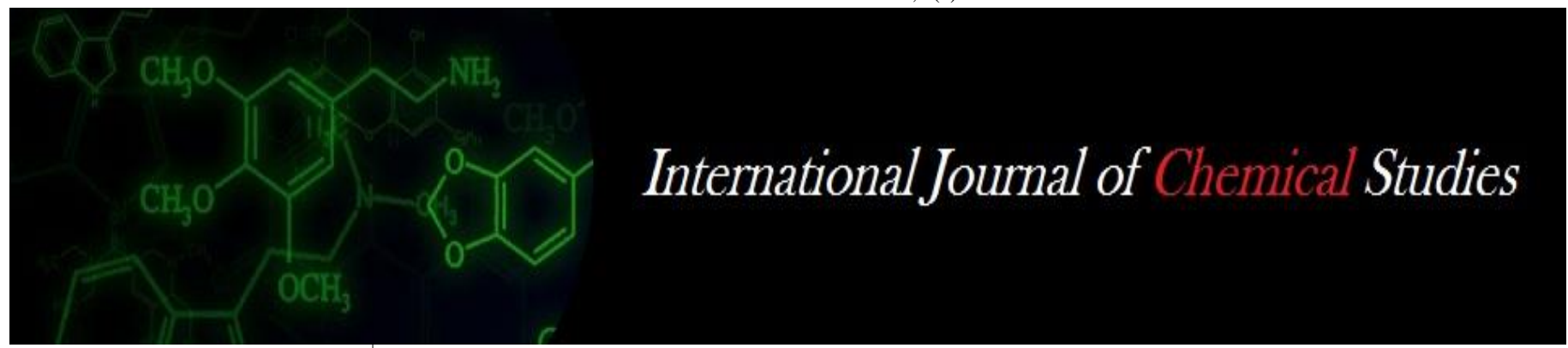

P-ISSN: 2349-8528

E-ISSN: 2321-4902

www.chemijournal.com

IJCS 2020; 8(5): 1227-1230

(C) 2020 IJCS

Received: 05-07-2020

Accepted: 13-08-2020

\section{JM Aal}

Department of Horticulture, B.

A. College of Agriculture, Anand Agricultural University, Anand,

Gujarat, India

\section{KM Patel}

Department of Horticulture, B.

A. College of Agriculture, Anand

Agricultural University, Anand,

Gujarat, India

\section{JC Rathva}

Department of Horticulture, B.

A. College of Agriculture, Anand

Agricultural University, Anand,

Gujarat, India

\section{SR Nadoda}

Department of Horticulture, B. A. College of Agriculture, Anand Agricultural University, Anand, Gujarat, India

\section{Corresponding Author:}

JM Aal

Department of Horticulture, B.

A. College of Agriculture, Anand

Agricultural University, Anand,

Gujarat, India

\section{Effect of integrated nutrient management on fruit quality and shelf life of Aonla (Emblica officinalis Gaertn.) cv. Gujarat Aonla - 1}

\author{
JM Aal, KM Patel, JC Rathva and SR Nadoda
}

DOI: https://doi.org/10.22271/chemi.2020.v8.i5q.10473

\begin{abstract}
An experiment was carried out to study the "Effect of integrated nutrient management on quality and shelf life of Aonla (Emblica officinalis Gaertn.) cv. Gujarat Aonla - 1" at Horticultural Research Farm and P.G. Laboratory, Department of Horticulture, B. A. College of Agriculture, Anand Agricultural University, Anand during Kharif-Rabi season of the year 2018-19. The experiment was laid out in completely randomized design with three repetitions. Among all the treatments, $\mathrm{T}_{9}(50 \% \mathrm{RDF}$ through chemical fertilizer $+25 \%$ RDN through vermicompost $+10 \mathrm{ml}$ Anubhav Bio NPK Consortium/tree) treatment was found most effective treatment and recorded significantly maximum in pulp weight at maturity stage, pulp:stone ratio at maturity stage, total soluble solids, ascorbic acid, shelf life and minimized the acidity in Aonla fruits.
\end{abstract}

Keywords: Aonla, INM, Ascorbic acid and shelf life

\section{Introduction}

Aonla (Emblica officinalis Gaertn.) belongs to family Euphorbiaceae and subfamily 'Phyllanthoidae'. It is native of Tropical South-East Asia, particularly in central and southern India. Aonla being hardy in nature and it is successfully cultivated in wide range of soil and climatic condition. Aonla is drought hardy fruit crop which is characterized by deep root system and exhibits deciduous nature due to abscission and shedding of determinate shoot during February and March. The success of Aonla cultivation under arid ecosystem is largely based on efficient management of available natural resources. The chemical composition of Aonla is found to be influenced by environmental factors. It has been found that the chemical parameters viz. total soluble solids, acidity, sugars, ascorbic acid, etc., change during growth and development of fruits. Total soluble solids, sugars and ascorbic acid gradually increased reaching the maximum at maturity, whereas acidity, phenol and tannin content decreased up to the minimum at maturity. The shelf life of Aonla fruit is 12-15 days under normal conditions. It becomes difficult to process entire fruit production in short span of time. At the peak harvest season, the availability of the fruits exceeds whereas the demand and the market price falls very low. The proper nutrient management approach is indispensable for sustaining high quality fruit production without detrimental effects on soil caused by inorganic fertilizers. It is also recognized that integrated nutrient management plays an important role in improving the soil fertility, physico-chemical conditions of soil and crop productivity.

Organic manures supply plants nutrients and micronutrients. They improve soil physical properties like soil structure, infiltration rate, porosity, water holding capacity, bulk density etc. and also increases the availability of nutrients. Organic manures act as a buffering agents and supplies food for beneficial living organisms. Biofertilizers are microbial preparations containing living cells of different microorganisms which have the ability to mobilize plant nutrients in soil from unusable to usable form through biological process. They are environmental friendly and play significant role in crop production. Hence, in order to develop a sustainable integrated nutrient management technology for Aonla, the present investigation was undertaken. Keeping the above facts in the mind, the present investigation was undertaken with an objective of finding out the effect of integrated nutrient management on quality and shelf life of Aonla. 


\section{Materials and Methods}

The present experiment was carried out at Horticultural Research Farm, and P.G. Laboratory, Department of Horticulture, B. A. College of Agriculture, Anand Agricultural University, Anand during Kharif-Rabi season of the year 2018-19. The experiment was laid out in completely randomized design with three repetitions comprising nine treatments. The soil of the experimental plot was sandy loam type. The chemical fertilizers like nitrogen, phosphorus and potash were applied in the form of urea, single super phosphate and murate of potash, respectively as per treatments. Half dose of nitrogen and full dose of phosphorus and potash was given one week after organic fertilizer application and remaining half dose of nitrogen given on $14^{\text {th }}$ September. Well decomposed FYM $100 \mathrm{~kg}$ per tree was given as common recommended basal dose of all the treatments, vermicompost and castor cake was applied as per treatments requirement on $10^{\text {th }}$ July. Biofertilizer i.e. Anubhav Bio NPK consortium was obtained from department of Agricultural Microbiology, Anand Agricultural University, Anand. It was applied $1 \mathrm{~m}$ away from main stem at the time of application of organic manures as mixing with FYM in the soil as per treatments. The mature and uniform sized fruits were harvested from the respective trees and observations were recorded regarding the yield parameters of the fruits.

\section{Results and Discussion}

The results obtained from the research experiment on effect of integrated nutrient management on quality and shelf life of Aonla are presented in Table 1 and 2.

The results revealed that effect of integrated nutrient management on internal necrosis affected fruits was found non-significant.

The application of integrated nutrient was significantly influenced on pulp weight at maturity stage. Significantly maximum pulp weight at maturity stage $(39.67 \mathrm{~g})$ was recorded under treatment $\mathrm{T}_{9}(50 \% \mathrm{RDF}$ through chemical fertilizer $+25 \%$ RDN through vermicompost $+10 \mathrm{ml}$ Anubhav Bio NPK Consortium/tree). It was statistically at par with the treatments $T_{2}, T_{3}, T_{4}$, and $T_{8}$. While, minimum pulp weight at maturity stage $(34.70 \mathrm{~g})$ was recorded in control. An increase in pulp weight of fruits might be on account of incorporation of organic manures and biofertilizers along with inorganic fertilizers. Organic manures and biofertilizers have direct role in nitrogen fixation, production of phytohormones like substances and increased uptake of nutrients hence quality improvement reflected in fruit characters. These observations are in agreement with the findings of Mandal et al. (2013) ${ }^{[6]}$ in Aonla Baviskar et al. (2011) ${ }^{[1]}$, Patel and Naik (2010) ${ }^{[10]}$ in sapota, Madhavi et al. (2008) ${ }^{[5]}$ in mango.

The results revealed that effect of integrated nutrient management on stone weight at maturity stage was found non-significant.

The results indicate that treatment $\mathrm{T}_{9}(50 \% \mathrm{RDF}$ through chemical fertilizer $+25 \%$ RDN through vermicompost +10 $\mathrm{ml}$ Anubhav Bio NPK Consortium/tree) was found significantly maximum in pulp:stone ratio at maturity stage (17.61). It was statistically at par with the treatments $T_{3}, T_{4}, T_{5}$ and $\mathrm{T}_{8}$. Whereas, minimum pulp:stone ratio at maturity stage (14.56) was recorded with control. This might be due to accumulation of more food material in the trees by an efficient utilization for development of fruits. The marked effect of nitrogen on fruit was due to increase in the efficiency of metabolic processes and thus encouraged the growth of the plant in general and consequently the various parts of the plant including fruit. The application of $\mathrm{N}, \mathrm{P}$ and $\mathrm{K}$ fertilizers might have resulted in high rate of photosynthesis results leads to higher carbohydrates accumulation in fruit and thereby increasing pulp: stone ratio of the fruit. The results reported by Mandal et al. (2013) ${ }^{[6]}$ and Singh et al. (2008) ${ }^{[15]}$ in Aonla, Nehete (2013) ${ }^{[7]}$ in mango, Verma et al. (2014) ${ }^{[18]}$ and Ram et al. (2012) ${ }^{[13]}$ in phalsa.

Table 1: Effect of integrated nutrient management on internal necrosis affected fruit, pulp weight, stone weight and pulp: stone ratio of Aonla cv. Gujarat Aonla - 1

\begin{tabular}{|c|c|c|c|c|c|}
\hline $\begin{array}{l}\text { Sr. } \\
\text { No. }\end{array}$ & Treatments & $\begin{array}{l}\text { Internal necrosis } \\
\text { affected fruit }(\%)\end{array}$ & $\begin{array}{c}\text { Pulp } \\
\text { weight }(g)\end{array}$ & $\begin{array}{c}\text { Stone } \\
\text { weight }(g)\end{array}$ & $\begin{array}{c}\text { Pulp: stone } \\
\text { ratio }\end{array}$ \\
\hline $\mathrm{T}_{1}$ & $100 \%$ RDF (1000:500:500 NPK g/tree) (Control) & 9.38 & 34.70 & 2.38 & 14.56 \\
\hline $\mathrm{T}_{2}$ & $\begin{array}{l}75 \% \text { RDF through chemical fertilizer + } 25 \% \text { RDN through castor } \\
\text { cake/tree }\end{array}$ & 9.11 & 37.72 & 2.32 & 15.28 \\
\hline $\mathrm{T}_{3}$ & $\begin{array}{l}50 \% \text { RDF through chemical fertilizer + 50\% RDN through castor } \\
\text { cake/tree }\end{array}$ & 8.95 & 38.25 & 2.23 & 17.13 \\
\hline $\mathrm{T}_{4}$ & $\begin{array}{l}75 \% \text { RDF through chemical fertilizer }+25 \% \text { RDN through } \\
\text { vermicompost/tree }\end{array}$ & 9.22 & 39.12 & 2.27 & 17.26 \\
\hline $\mathrm{T}_{5}$ & $\begin{array}{l}50 \% \text { RDF through chemical fertilizer }+50 \% \text { RDN through } \\
\text { vermicompost/tree }\end{array}$ & 9.29 & 36.60 & 2.29 & 15.96 \\
\hline $\mathrm{T}_{6}$ & $\begin{array}{l}75 \% \text { RDF through chemical fertilizer }+10 \mathrm{ml} \text { Anubhav Bio NPK } \\
\text { Consortium/tree }\end{array}$ & 9.39 & 36.39 & 2.34 & 15.57 \\
\hline $\mathrm{T}_{7}$ & $\begin{array}{l}50 \% \text { RDF through chemical fertilizer }+20 \mathrm{ml} \text { Anubhav Bio NPK } \\
\text { Consortium/tree }\end{array}$ & 9.36 & 36.29 & 2.36 & 15.35 \\
\hline $\mathrm{T}_{8}$ & $\begin{array}{c}50 \% \text { RDF through chemical fertilizer }+25 \% \text { RDN through castor cake }+ \\
10 \mathrm{ml} \text { Anubhav Bio NPK Consortium/tree }\end{array}$ & 9.15 & 37.48 & 2.29 & 16.34 \\
\hline $\mathrm{T}_{9}$ & $\begin{array}{c}50 \% \text { RDF through chemical fertilizer }+25 \% \text { RDN through vermicompost } \\
+10 \mathrm{ml} \text { Anubhav Bio NPK Consortium/tree }\end{array}$ & 8.99 & 39.67 & 2.25 & 17.61 \\
\hline \multicolumn{2}{|r|}{ S.Em. \pm} & 0.53 & 0.92 & 0.04 & 0.62 \\
\hline \multicolumn{2}{|r|}{ C.D. at 5\% } & NS & 2.74 & NS & 1.84 \\
\hline \multicolumn{2}{|r|}{ C.V. \% } & 9.90 & 4.27 & 2.85 & 6.67 \\
\hline
\end{tabular}

Significantly maximum total soluble solids $\left(16.54{ }^{0}\right.$ Brix $)$ was recorded under treatment $\mathrm{T}_{9}(50 \% \mathrm{RDF}$ through chemical fertilizer $+25 \%$ RDN through vermicompost $+10 \mathrm{ml}$ Anubhav Bio NPK Consortium/tree). It was statistically at par with the treatments $T_{2}, T_{4}, T_{5}$ and $T_{8}$. While, significantly minimum total soluble solids $\left(14.30{ }^{0}\right.$ Brix $)$ was recorded in control. An increase in total soluble solids might be due to beneficial role of nutrient on the process of photosynthesis 
which ultimately led to the accumulation of large amount of carbohydrates and increase in total soluble solid content of fruits. The vermicompost play important role in placing the nutrient and plant hormones, which are directly or indirectly involved in improving the fruit quality. Similar results were also obtained by Yadav et al. (2013) ${ }^{[20]}$ in Aonla, Ram et al. (2012) ${ }^{[13]}$ and Sutariya et al. (2018) ${ }^{[16]}$ in phalsa. Ingle et al. (2001) [4] in acid lime, Dubey and Yadav (2003) [2] and Ramamurthy et al. (2006) ${ }^{[14]}$ in mandarin, Patel et al. (2009) ${ }^{[11]}$ in sweet orange, Yadav et al. $(2011)^{[19]}$ in papaya.

Significantly minimum acidity $(1.82 \%)$ was noted in treatment $\mathrm{T}_{9}(50 \%$ RDF through chemical fertilizer $+25 \%$ RDN through vermicompost $+10 \mathrm{ml}$ Anubhav Bio NPK Consortium/tree). It was statistically at par with the treatments $\mathrm{T}_{2}, \mathrm{~T}_{4}, \mathrm{~T}_{5}$ and $\mathrm{T}_{8}$. While, significantly maximum acidity (1.92 $\%$ ) was recorded in $\mathrm{T}_{1}$ (control). It is obtained that acidity decrease due to an increase in total soluble solids and total sugar. The results reported by Yadav et al. (2013) [21] in Aonla, Ram et al. (2012) ${ }^{[13]}$ and Sutariya et al. (2018) ${ }^{[16]}$ in phalsa, Dubey and Yadav (2003) ${ }^{[2]}$ in mandarin, Patel et al. (2009) ${ }^{[11]}$ in sweet orange, Nurbhanej et al. (2016) ${ }^{[8]}$ in acid lime and Ram et al. (2007) ${ }^{[7]}$ in guava.

Significantly maximum ascorbic acid content $(845.17 \mathrm{mg} / 100$ g pulp) was recorded under treatment $\mathrm{T}_{9}(50 \% \mathrm{RDF}$ through chemical fertilizer $+25 \%$ RDN through vermicompost +10 $\mathrm{ml}$ Anubhav Bio NPK Consortium/tree). It was statistically at par with the treatments $\mathrm{T}_{2}, \mathrm{~T}_{3}, \mathrm{~T}_{4}, \mathrm{~T}_{5}$ and $\mathrm{T}_{8}$. While, significantly minimum as corbic acid content $(797.77 \mathrm{mg} / 100$ $\mathrm{g}$ pulp) was recorded in $\mathrm{T}_{1}$ (control). This is might be due to nutrient stimulated the functioning of number of enzymes in the physiological process and proper supply of nutrient induced the photosynthesis carbohydrate and sugar metabolisms which improved the quality of fruits. The vermicompost play an important role in placing the nutrient and plant hormones, which are directly or indirectly involved in improving the fruit quality. Similar trends were also observed by Yadav et al. (2013) ${ }^{[20]}$ in Aonla, Ram et al. (2012) ${ }^{[13]}$ and Sutariya et al. (2018) ${ }^{[16]}$ in phalsa. Nurbhanej et al. (2016) ${ }^{[8]}$ and Ingle et al. (2001) ${ }^{[4]}$ in acid lime, Dubey and Yadav (2003) ${ }^{[2]}$ in mandarin, Patel et al. (2009) ${ }^{[11]}$ in sweet orange, Yadav et al. (2011) ${ }^{[19]}$ in papaya, Yadav et al. (2011) ${ }^{[19]}$ in mango.

It is clear from the results that treatment $\mathrm{T}_{9}(50 \% \mathrm{RDF}$ through chemical fertilizer $+25 \%$ RDN through vermicompost $+10 \mathrm{ml}$ Anubhav Bio NPK Consortium/tree) was most effective treatment and which was recorded significantly maximum shelf life (17.33 day). It was statistically at par with the treatments $\mathrm{T}_{4}, \mathrm{~T}_{5}$ and $\mathrm{T}_{8}$. While, significantly minimum shelf life (12.03 day) was recorded in control. This extended shelf life has been the consequence of slow down the ethylene synthesis and ultimately ripening process through minimum reduction in weight loss and other physiological parameters as well as bio-chemical changes in fruits. The results of present findings are in conformation with the earlier workers Patel et al. (2017) ${ }^{[10]}$, Patel and Naik (2010) ${ }^{[10]}$ in sapota, Thakkar (2015) ${ }^{[17]}$ and Godage et al. $(2013)^{[3]}$ in guava.

Table 2: Effect of integrated nutrient management on total soluble solids, acidity, ascorbic acid and shelf life of Aonla cv. Gujarat Aonla - 1

\begin{tabular}{|c|c|c|c|c|c|}
\hline $\begin{array}{l}\text { Sr. } \\
\text { No }\end{array}$ & Treatments & $\begin{array}{c}\text { TSS } \\
\left({ }^{(0} \text { Brix }\right)\end{array}$ & $\begin{array}{c}\text { Acidity } \\
(\%)\end{array}$ & $\begin{array}{c}\text { Ascorbic acid } \\
\text { (mg/100 g pulp) }\end{array}$ & $\begin{array}{c}\begin{array}{c}\text { Shelf life } \\
\text { (days) }\end{array} \\
\end{array}$ \\
\hline $\mathrm{T}_{1}$ & $100 \%$ RDF (1000:500:500 NPK g/tree) (Control) & 14.30 & 1.92 & 797.77 & 12.03 \\
\hline $\mathrm{T}_{2}$ & $75 \%$ RDF through chemical fertilizer $+25 \%$ RDN through castor cake/tree & 15.30 & 1.87 & 822.83 & 15.19 \\
\hline $\mathrm{T}_{3}$ & $50 \%$ RDF through chemical fertilizer $+50 \%$ RDN through castor cake/tree & 14.98 & 1.89 & 816.81 & 14.90 \\
\hline $\mathrm{T}_{4}$ & $75 \%$ RDF through chemical fertilizer + $25 \%$ RDN through vermicompost/tree & 15.34 & 1.86 & 834.56 & 16.63 \\
\hline $\mathrm{T}_{5}$ & $50 \%$ RDF through chemical fertilizer $+50 \%$ RDN through vermicompost/tree & 16.11 & 1.83 & 828.57 & 16.90 \\
\hline $\mathrm{T}_{6}$ & $\begin{array}{l}75 \% \text { RDF through chemical fertilizer }+10 \mathrm{ml} \text { Anubhav Bio NPK } \\
\text { Consortium/tree }\end{array}$ & 14.61 & 1.90 & 809.55 & 14.19 \\
\hline $\mathrm{T}_{7}$ & $\begin{array}{l}50 \% \text { RDF through chemical fertilizer }+20 \mathrm{ml} \text { Anubhav Bio NPK } \\
\text { Consortium/tree }\end{array}$ & 14.35 & 1.91 & 801.04 & 14.02 \\
\hline $\mathrm{T}_{8}$ & $\begin{array}{l}50 \% \mathrm{RDF} \text { through chemical fertilizer }+25 \% \mathrm{RDN} \text { through castor cake }+10 \mathrm{ml} \\
\text { Anubhav Bio NPK Consortium/tree }\end{array}$ & 15.71 & 1.84 & 839.60 & 16.86 \\
\hline $\mathrm{T}_{9}$ & $\begin{array}{l}50 \% \text { RDF through chemical fertilizer }+25 \% \text { RDN through vermicompost }+10 \\
\text { ml Anubhav Bio NPK Consortium/tree }\end{array}$ & 16.54 & 1.82 & 845.17 & 17.33 \\
\hline & S. Em. \pm & 0.48 & 0.02 & 10.50 & 0.72 \\
\hline & C.D. at 5\% & 1.42 & 0.07 & 31.19 & 2.13 \\
\hline & C.V. $\%$ & 5.41 & 2.25 & 2.21 & 8.11 \\
\hline
\end{tabular}

\section{Conclusion}

The result obtained from research experiment, it can be concluded that $50 \% \mathrm{RDF}$ through chemical fertilizer $+25 \%$ RDN through vermicompost $+10 \mathrm{ml}$ Anubhav Bio NPK Consortium/tree was found beneficial to increases pulp weight at maturity stage, pulp: stone ratio at maturity stage, total soluble solids, ascorbic acid, shelf life and minimized the acidity in Aonla cv. Gujarat Aonla - 1.

\section{References}

1. Baviskar MN, Bharad SG, Dod VN, Barne VG. Effect of integrated nutrient management on yield and quality of sapota. Plant Archives. 2011; 11(2):661-663.

2. Dubey AK, Yadav DS. Response of Khasi mandarin (Citrus reticulata Blanco) to organic versus inorganic fertilization. The Indian J of Agric. Research. 2003; 37(3):214-218.

3. Godage SS, Parekh NS, Nehte DS. Influence of biofertilizers in combination with chemical fertilizers on growth, yield and quality of guava cv. Allahabad Safeda. Int. J of Agril. Sci. 2013; 9(1):309-313.

4. Ingle HV, Athawale RB, Ghawde SM, Shivankar SK. Integrated nutrient management in acid lime. South Indian J of Hort. 2001; 49:126-129.

5. Madhavi A, Prasad VM, Girwani A. Integrated nutrient management in mango. Orissa J of Hort. 2008; 36(1): 6468.

6. Mandal KK, Rajak A, Debnath Hasan MA. Integrated nutrient management in Aonla cv. NA -7 in the red lateritic region of West Bengal. J of crop and weed. 2013; 9(1):121-123. 
7. Nehete DS. Influence of biofertilizers in combination with chemical fertilizers on growth, yield and quality of mango (Mangifera indica L.) cv. Amrapali. Unpublished Ph.D. Theses submitted to AAU, Anand, Gujarat, 2013.

8. Nurbhanej KH, Patel MJ, Barot HR, Thakkar RM, Gadhavi AV. Effect of integrated nutrient management on growth, yield and quality of acid lime cv. Kagzi. Int. J of Agri. Sci. 2016; 8(51):2360-2363.

9. Patel DR, Naik AG. Effect of pre harvest treatment of organic manure and inorganic fertilizers on post-harvest shelf life of sapota cv. Kalipatti. The Indian J of Hort. 2010; 67(3):381-386.

10. Patel M, Vihol NJ, Patel AD, Patel HC. Effect of integrated nutrient management on quality parameters of sapota cv. Kalipatti. Int. J of Chem. Studies. 2017; 5(6):889-891.

11. Patel VB, Singh AK, Singh L. Microbial and inorganic fertilizers application influenced vegetative growth, yield, leaf nutrient status and soil microbial biomass in sweet orange cv. Mosambi. Indian J of Hort. 2009; 66(2):163168.

12. Ram RA, Bhriguvanshi SR, Pathak RK. Integrated plant nutrient management in guava (Psidium guajava L.) cv. Sardar. Acta Hort. 2007; 735:345-350.

13. Ram RB, Kuldeep Meena ML, Lata R, Bharti N. Effect of integrated nutrient management for some quality character of phalsa. The Asian J of Hort. 2012; 7(2):385387.

14. Ramamurthy V, Jagdish P, Prahad VN, Thakre V. Vermicompost application improves the productivity and quality of Nagpur mandarin (Citrus raticulata Blanco). Organic Farming Newsletter. 2006; 2(3):5.

15. Singh A, Yadav AL, Yadav DK, Misra SK. Effect of integrated nutrient management of yield and quality of Aonla (Emblica officinalis Gaertn) cv. NA-10. Plant Archives. 2008; 8(1):473-474.

16. Sutariya NK, Patel MJ, Patel HA, Vasara RP. Effect of integrated nutrient management on bio chemical parameters of phalsa (Grewia subinaequalis L.) cv. Local. J of Pharmacognosy and Phytochemistry. 2018 b; 7(5):408-411.

17. Thakkar RM. Integrated nutrient management on growth, yield and quality of guava (Psidium guajava L.) cv. Allahabad Safeda. Unpublished Ph.D. Theses, AAU, Anand, 2015.

18. Verma RS, Singh HK, Verma SS. Effect of integrated nuitrent management on plant growth, yield and quality of phalsa (Grewia subinaqualis). The Asian $\mathrm{J}$ of Hort. 2014; 9(1):48-52.

19. Yadav AK, Singh JK, Singh HK. Studies on integrated nutrient management in flowering, fruiting, yield and quality of mango cv. Amrapali under high density orcharding. Indian J of Hort. 2011; 68(4):453-460.

20. Yadav HC, Yadav AL, Singh HK, Yadav DK. Effect of organic manures on fruit quality and soil health of Aonla (Emblica officinalis Gaertn.) cv. NA-6. Plant Archives. 2013; 13(1):513-515.

21. Yadav PK, Yadav AL, Yadav AS, Yadav HC, Singh YP. Effect of integrated nutrient nourishment on yield attributes and economics of papaya (Carica papaya L.) cv. Pusa Dwarf. Plant Archives. 2011; 11(1):307-309. 